Running title: Protein and mRNA quantification in small hiPSC-CMs samples

\title{
Protein and mRNA quantification in small samples of human induced pluripotent stem-cell-derived cardiomyocytes in 96-well microplates
}

\author{
Weizhen Li, Julie L. Han and Emilia Entcheva* \\ Department of Biomedical Engineering, The George Washington University, Washington DC
}

*Corresponding author

Emilia Entcheva, $\mathrm{PhD}$,

Department of Biomedical Engineering

George Washington University

800 22nd St NW, Suite 5000

Washington, DC 20052

entcheva@gwu.edu 


\section{Summary/Abstract}

We describe a method for protein quantification and for mRNA quantification in small sample quantities of human induced pluripotent stem-cell-derived-cardiomyocytes (hiPSC-CMs). Demonstrated here is how the capillary-based protein detection system $\mathrm{Wes}^{\mathrm{TM}}$ by ProteinSimple and the Power SYBR ${ }^{\mathrm{TM}}$ Green Cells-to-CT ${ }^{\mathrm{TM}}$ Kit by Invitrogen can be applied to individual samples in a 96-well microplate format and thus made compatible with high-throughput (HT) cardiomyocyte assays. As an example of the usage, we illustrate that Cx43 protein and GJA1 mRNA levels in hiPSC-CMs are enhanced when the optogenetic actuator, channelrodopsin-2 (ChR2), is genetically expressed in them. Instructions are presented for cell culture and lysate preparations from hiPSC-CMs, along with optimized parameter settings and experimental protocol steps. Strategies to optimize primary antibody concentrations as well as ways for signal normalization are discussed, i.e. antibody multiplexing and total protein assay. The sensitivity of both the Wes and Cells-to-CT kit enables protein and mRNA quantification in a HT format, which is important when dealing with precious small samples. In addition to being able to handle small cardiomyocyte samples, these streamlined and semi-automated processes enable quick mechanistic analysis.

\section{Key Words}

High-throughput, hiPSC-CMs, Wes ${ }^{\mathrm{TM}}$ ProteinSimple, Cells-to-CT ${ }^{\mathrm{TM}}, \mathrm{Cx} 43$, ChR2, optogenetic 


\section{Introduction}

Human stem-cell-derived cardiomyocytes are an important driver in personalized medicine through the development of patient-specific high-throughput assays(1-4). These assays yield a range of functional outputs from viability to metabolic function to arrhythmia predictions using all-optical or other technologies(5-10). It is essential to be able to perform quick analysis of protein and gene expression with minimal cell material, compatible with the HT format of these functional assays.

Western Blots (WB) have been widely used for protein quantification since their development in the 1970s (11-13). In traditional WB, protein samples are denatured and separated based on molecular weights by SDS-PAGE (sodium dodecyl sulfate, SDS - polyacrylamide gel electrophoresis, PAGE). The separated protein components are transferred onto either nitrocellulose membrane or PVDF (polyvinylidene fluoride) for target protein immunoprobing and chemiluminescent quantification. While this classic WB method is widely used, it is difficult to detect targets in total protein amounts less than $8 \mu \mathrm{g}$ per sample. Thus, it cannot be used to detect protein expression levels in small cell collections completed in 96-well format.

Improvements of the technique have been made to increase the detection sensitivity, throughput and reproducibility. Utilizing sequential lateral flow, automation of the immunoprobing steps is commercially available from iBind (Thermo Fisher). A bead-based microarray assay immobilizes separated protein components onto hundreds of microspheres and achieves high-throughput by analyzing bead collections (14). Microfluidics-based immunoassays have integrated protein separation and detection in microchips (15-17) which has allowed for the reduction of starting material to a single cell level (18). Capillary electrophoresis-based approaches have also been 
pursued, with dispersion or ligand binding to generate signals along a narrow capillary at nanoliter volumes for high sensitivity quantification with also very small starting material $(19,20)$.

Based on capillary electrophoresis, the $\mathrm{Wes}^{\mathrm{TM}}$ ProteinSimple platform for protein quantification was commercialized and has demonstrated high sensitivity, wide dynamic range and good reproducibility (21-23). Since deployment, it has been widely used in cancer $(24,25)$ and neuroscience $(26,27)$, with some recent applications to cardiac research (28-34). The key advantages of this system over standard WB include the small starting material needed (as low as $0.8 \mu \mathrm{g}$ per sample), the level of automation and high throughput (runs up to 24 samples concurrently) and faster turnover (3-5 hours assay time), all of which make it ideal for applications requiring analysis of many protein samples limited by size. Due to high-cost considerations and the need for high-throughput mechanism insights into drug screening applications with human cells, such a system for protein quantification is particularly valuable for studies with human induced pluripotent stem cell-derived cardiomyocytes (hiPSC-CMs). Indeed, the Wes has been already applied in several cases recently, including signaling pathway inquiries with hiPSC-CMs (35), cardiac pharmacology and toxicology (36), hiPSC differentiation (37,38), gene therapy (39) and quantifying ion channel expression to assess maturity(34).

It is often useful and/or more straightforward to perform gene expression analysis as a surrogate or as a complement to protein quantification. The basis of the current "gold standard" in quantifying gene expression is the polymerase-chain-reaction (PCR) method developed in the 1980s by Mullis (40,41). A variety of newer techniques have emerged in this area, including the quantitative reverse-transcription qPCR, application of microarrays and RNAseq, extending recently to single-cell and spatial transcriptomics(42). 
Critical developments in the 1990s included the use of fluorescent labeling for kinetic (real-time) qPCR to quantify mRNA $(43,44)$. This allows for very sensitive detection of gene expression in small samples. Rigorous quantification of mRNA based on a critical time or threshold cycle $(\mathrm{Ct})$ from the amplification curves was developed (45-47). To further streamline the process and eliminate the RNA isolation step, the direct "Cells-to-CT" method (48) was made commercially available. In this method, the cell lysate is directly incorporated in the qPCR workflow, which makes the process faster and enables further reduction of sample size needed to run the reactions. This technique has been applied to human iPSC-CMs and human cardiovascular progenitor cells in a limited number of studies $(34,49-51)$.

Here, we provide a detailed protocol of protein detection using the Wes and mRNA quantification using the Cells-to-CT kit and qPCR in hiPSC-CMs samples in a 96-well format, overview in Figure 1. Frequently used system settings, sample preparation, antibody linear dynamic range test, antibody multiplexing dilutions, and recommended qPCR settings are summarized in tables for reference. Optimization of antibody multiplexing is illustrated using several pairs of proteins in hiPSC-CMs - with options to extend the method to other protein targets.

Using this method, we demonstrate the potential influence of ChR2 on connexin43 (Cx43) in hiPSC-CMs. ChR2 is introduced into hiPSC-CMs by adenoviral infection and comparison was done with respect to both non-infected samples and an Ad-eYFP control. In the presence of ChR2, there is an increase of GJA1 at the transcriptional level and enhanced expression of the Cx43 protein in hiPSC-CMs. 


\section{Materials and Reagents}

\section{1. hiPSC-CMs cell culture}

1. Human induced pluripotent stem cell-derived cardiomyocytes iCell Cardiomyocytes ${ }^{2}$ CMC-100-012-001, derived from a female donor, purchased from Fujifilm Cellular Dynamics International.

2. MyCell hiPSC-CM-1X 01395, derived from a male donor, purchased from Fujifilm Cellular Dynamics International.

3. Cell plating medium and maintenance medium are provided by the manufacturer (Fujifilm Cellular Dynamics International).

4. Fibronectin (Corning)

5. 1X phosphate buffered saline (PBS)

6. 96-well glass bottom plate (Cellvis)

7. (optional to illustrate usage by adenoviral infection) Ad-CMV-hChR2 (H134R)-eYFP (Vector Biosystems Inc.)

8. (optional to illustrate usage by adenoviral infection) Ad-CMV-eYFP as a control (Vector Biosystems Inc.)

\subsection{Cell lysis and protein denaturing for WB}

1. 1X PBS

2. Qproteome Mammalian Protein Prep Kit (Qiagen)

3. Sterile $1.5 \mathrm{~mL}$ microcentrifuge tubes

4. Plate shaker, Figure 2a 
5. Refrigerated high-speed Eppendorf centrifuge (Millipore-Sigma), Figure 2b

6. Heat block with inserts for microcentrifuge tubes, Figure 2c

7. Microcentrifuge/spinner, Figure 2d

8. PlateFuge plate centrifuge, Figure 2e

\subsection{Immunoprobing}

1. Kit for running an assay by Protein Simple, containing:
a. Jess/Wes 25-capillary cartridge, Figure $2 \mathbf{f}$.
b. Jess/Wes separation module $(12-230 \mathrm{kDa})$ with a pre-filled microplate with split running buffer, Figure 2g.
c. Wash buffer and 10X sample buffer.
d. EZ standard pack with lyophilized material in three tubes, as follows: biotinylated ladder, fluorescent standard 5X master mix and dithiothreitol (DTT).

2. Wes system (Protein Simple), Figure $\mathbf{2 h}$.

3. Primary antibodies tested in this study:
a. Cx43 (ab11370), Abcam
b. Kir2.1 (ab65796), Abcam
c. alpha-tubulin (ab7291), Abcam
d. GAPDH (ab181602), Abcam
e. LDH (H-10) (sc-133123), Santa Cruz. 
4. Secondary antibodies were anti-mouse and anti-rabbit detection modules (Protein Simple), which contained luminol, peroxide, milk-free antibody diluent and streptavidin-HRP in addition to anti-mouse/ anti-rabbit secondary HRP antibody.

5. PlateFuge plate centrifuge, Figure 2e.

6. Pipettes and tips.

\section{4. qPCR with the Cells-to-CT ${ }^{\mathrm{TM}}$ kit}

1. Power SYBR Green Cells-to-CT ${ }^{\mathrm{TM}}$ kit (Thermo Fisher)

2. 1X TE Buffer, pH 8.0

3. MicroAmp ${ }^{\mathrm{TM}}$ Optical 96-well Reaction Plate (Thermo Fisher)

4. MicroAmp ${ }^{\mathrm{TM}}$ Optical Adhesive Film Kit (Thermo Fisher)

5. QuantStudio ${ }^{\text {TM }} 3$ Real-Time PCR instrument (Thermo Fisher)

6. Thermal cycler (Eppendorf)

7. QuantStudio ${ }^{\mathrm{TM}}$ Design \& Analysis Software (Thermo Fisher) was used for to conduct differential expression analysis

8. Nuclease-free microcentrifuge tubes and pipette tips

\section{Methods}

The detailed workflow for protein quantification is illustrated in Figure 2, with relevant equipment shown.

\subsection{Culturing hiPSC-CMs in a 96-well plate $(50,000$ cells per well)}


Thawing and plating of hiPSC-CMs is done following manufacturer's instructions, adapted by user and summarized as follows:

1. Thaw the commercial plating and maintenance medium at $4^{\circ} \mathrm{C}$ overnight; equilibrate to room temperature upon usage.

2. Coat wells (in the 96 -well plate) with $100 \mu \mathrm{l}$ of $50 \mu \mathrm{g} / \mathrm{mL}$ fibronectin diluted in $1 \mathrm{X}$ sterile PBS in $37^{\circ} \mathrm{C}$ cell culture incubator for at least 2 hours. Remove fibronectin solution right before cell plating.

3. Immediately transfer hiPSC-CMs cryovial from liquid nitrogen to $37^{\circ} \mathrm{C}$ water bath. Hold the cryovial using floating tube rack and immerse the cryovial in $37^{\circ} \mathrm{C}$ water bath for 3 min without submerging the cap (see note 1).

4. Move the cryovial into the biosafety cabinet after sterilizing with $70 \%$ ethanol.

5. Transfer $1 \mathrm{~mL}$ of cell suspension from the cryovial into a $50 \mathrm{~mL}$ conical tube. Use $1 \mathrm{~mL}$ cell plating medium to rinse the remaining cells in cryovial and add dropwise into the cell suspension at a rate of 1 drop per 5 seconds and swirl between drops.

6. Gently drop additional $8 \mathrm{~mL}$ cell plating medium into the $50 \mathrm{~mL}$ conical tube for a total of $10 \mathrm{ml}$ solution, slowly swirl the tube in the process.

7. Gently plate $100 \mu \mathrm{L}$ cell suspension into each 96 -well for a plating density of 50,000 cells per well. Slowly swirl the conical tube while plating as cells will settle over time.

8. Place the plate into $37^{\circ} \mathrm{C}$ cell culture incubator after plating, exchange plating media to maintenance medium 4 hours after the thaw. 
9. Gently replace maintenance medium every 2-3 days. Tilt the plate 45 degree and add in medium along the edges. Avoid dropping culture medium directly onto the cell layer (see note 2).

\subsection{Adenovirus infection - optional to illustrate usage}

1. Start adenovirus infection 5 days after cell plating.

2. Thaw adenovirus from $-80^{\circ} \mathrm{C}$ to $4^{\circ} \mathrm{C}$ on ice. Predilute the virus in sterile $1 \mathrm{x}$ PBS.

3. Conduct infection in maintenance media at multiplicity of infection (MOI 50). For calculations, follow the detailed published protocols $(52,53)$.

4. After 2 hours of incubation at $\left(37^{\circ} \mathrm{C}, 5 \% \mathrm{CO}_{2}\right)$, exchange viral medium with normal maintenance medium.

5. Collect cell lysates 48 hours after infection.

\subsection{Protein collection from a 96-well microplate}

1. Prepare QProteome Mammalian Protein lysis buffer and store on ice. Conduct all subsequent steps on ice.

2. Place the 96-well plate on ice. Aspirate cell culture medium and wash with cold 1x PBS. Completely aspirate the $1 \mathrm{X}$ PBS and add $10 \mu 1$ protein lysis buffer in each well.

3. After adding the lysis buffer, incubate on ice with shake for $5 \mathrm{~min}$.

4. Scrape each well and collect complete lysate into epitubes (see note 3).

5. Centrifuge all samples at $2000 \mathrm{rpm}$ for $30 \mathrm{~min}$ at $4^{\circ} \mathrm{C}$ and separate the supernatant (lysate) from the pellet. 
6. Transfer the samples to $-80^{\circ} \mathrm{C}$ freezer for long term storage. Upon usage, thaw samples on ice.

\subsection{Protein quantification using $\mathrm{Wes}^{\mathrm{TM}}$}

An overview of the process for protein quantification using the Wes is illustrated in Figure 2. In the Wes workflow, the cell lysates and reagents, including the primary antibodies and secondary horseradish peroxidase (HRP) antibodies, are loaded into small compartments in a special assay microplate (25 samples). The microplate is placed onto the system and interfaces a cassette with 25 thin capillaries. Size-based separation of proteins occurs as the proteins migrate in the separation matrix within the capillaries and are immobilized to the walls using proprietary photoactivated chemistry. Within 3-5 hours, the protein components in each sample are separated based on molecular weight, immobilized in the capillaries and detected using chemiluminescence. System readout is in the form of digitized "electropherograms", which can be converted to virtual or "pseudo" blot lanes automatically. Target peaks are quantified as area under the curve.

\subsubsection{Experiment planning and setting the Compass software}

It is crucial to carefully plan the sample layout and to enter all system settings in the software before running an assay.

1. Each $10 \mu \mathrm{L}$ cell lysate, obtained from a 96-well plate sample, allows for several Wes protein quantification runs, depending on protein target expression levels. For lower-expressing proteins, e.g. Kir2.1 in hiPSC-CMs, undiluted (or "neat") samples are preferred and cell lysates from one 96-well may be enough for up to two runs. For abundantly expressed proteins like LDH, Cx43 and GAPDH, samples can be diluted up to four times (see note 4). 
2. Based on the primary antibody's dilution factor and testing well number, one can calculate the primary antibody volume needed. Prepare for one more well to account for pipette errors.

3. Create a new file in the Compass software based on the type of assay. Choose 'Wes size' for typical immunoassay, including antibody multiplexing, or choose 'Wes total protein' if testing samples include total protein detection. There are some differences between the two programs, e.g. the total protein assay has $30 \mathrm{~min}$ of biotin labelling time instead of antibody diluent time in the immunoassay. Frequently used system settings are summarized in Table 1.

4. Enter the sample layout and primary antibodies attributes in the software. Adjust the running parameters. Save the file and print out the layout for referencing on the experimental day.

Table 1. Frequently used system setting

\begin{tabular}{|c|c|c|}
\hline Parameters & Wes size run & Total protein run \\
\hline Separation matrix load time & $200 \mathrm{sec}$ & $200 \mathrm{sec}$ \\
\hline Stacking matrix load time & $15 \mathrm{sec}$ & $18 \mathrm{sec}$ \\
\hline Sample load time & $9 \mathrm{sec}$ & $31 \mathrm{~min}$ \\
\hline Separation time & $31 \mathrm{~min}$ & $375 \mathrm{volts}$ \\
\hline Separation voltage & $375 \mathrm{volts}$ & $4 \mathrm{sec}$ \\
\hline Standards exposure & $4 \mathrm{sec}$ & $200 \mathrm{sec}$ \\
\hline EE immobilization time & $200 \mathrm{sec}$ & $/$ \\
\hline Antibody diluent time & $30 \mathrm{~min}$ & \\
\hline
\end{tabular}




\begin{tabular}{|c|c|c|}
\hline Biotin labeling time & $/$ & $30 \mathrm{~min}$ \\
\hline Primary antibody time & $30 \mathrm{~min}$ & $30 \mathrm{~min}$ \\
\hline Secondary antibody time & $30 \mathrm{~min}$ & $30 \mathrm{~min}$ \\
\hline
\end{tabular}

\subsubsection{Sample and primary antibody preparation for protein quantification}

1. Thaw samples from $-80^{\circ} \mathrm{C}$ freezer on ice.

2. Preset temperature of the heat block to $75^{\circ} \mathrm{C}$.

3. Start the Wes and the Compass software. Initiate the instrument self-test and save the result. If failure occurs - try again and report the problem if it persists.

4. Open an EZ standard pack and prepare the reagents following the manufacturer's instructions.

5. Dilute the 10x sample buffer to $0.1 \mathrm{x}$ buffer to dilute the cell lysates as needed. For analysis of low-abundance proteins, the cell lysates should be used "neat" (undiluted).

6. Mix cell lysates with the $5 \mathrm{X}$ fluorescent master mix 1:4 (lysate: fluorescent mix).

7. Denature all samples at $75^{\circ} \mathrm{C}$ for $10 \mathrm{~min}$ (or at $90^{\circ} \mathrm{C}$ for $5 \mathrm{~min}$ ) on heat block. Vortex and spin the tubes before and after the heating to ensure that the cell lysate and the fluorescent master mix are well homogenized.

8. Place the denatured samples back on ice and spin them in a centrifuge for 5 min at 2500 rpm at room temperature before sample loading. 
9. Dilute the primary antibodies with Antibody Diluent2, based on intended final concentration. Working concentrations of each antibody will need optimization as necessary concentrations are antibody dependent. Store in the pre-labeled microcentrifuge tubes.

\subsubsection{Microplate loading and start of a Wes run}

For reagent loading into the microplates, please see Figure 3 and details below.

1. Take the sealed microplate from the Jess/Wes separation module. To minimize the microwell exposure, peel the Wes microplate foil row by row when pipetting.

2. Loading row A: pipet $5 \mu \mathrm{L}$ biotinylated ladder in the first well of row A. Pipet $3 \mu \mathrm{L}$ of each prepared protein sample into the remaining 24 wells of the microplate. (see note 5)

3. For the biotinylated ladder column (default is the first column), pipet $10 \mu \mathrm{L}$ of Antibody Diluent2 in row B \& C, $10 \mu \mathrm{L}$ of Streptavidin-HRP in row D.

4. Loading rows $\mathrm{B}, \mathrm{C}$ and $\mathrm{D}$ with antibody diluent2, primary and secondary antibodies:

4a. For running an immunoassay, for each of the 24 sample wells, pipette $10 \mu \mathrm{L}$ of Antibody Diluent 2 in row $\mathrm{B}, 10 \mu \mathrm{L}$ primary antibody in Row $\mathrm{C}$ and $10 \mu \mathrm{L}$ of the corresponding secondary antibody in row D.

$4 \mathrm{~b}$. For running a total protein assay, for each of the 24 sample wells, pipette $10 \mu \mathrm{L}$ of Biotinylation reagent in row $\mathrm{B}, 10 \mu \mathrm{L}$ of Antibody Diluent 2 in row $\mathrm{C}$ and $10 \mu \mathrm{L}$ of total protein SA-HRP in row D.

5. Loading row E: Mix $200 \mu \mathrm{L}$ of Luminol with $200 \mu \mathrm{L}$ of Peroxide and fill row E with 15 $\mu \mathrm{L}$ of Luminol-Peroxide mixture in each well. 
6. Cover the microplate with its lid and centrifuge at $2500 \mathrm{rpm}$ for $5 \mathrm{~min}$ (using the PlateFuge) at room temperature to eliminate all bubbles; use an unopened microplate for balance.

7. Fill the first three rows of the bigger compartments on the microplate with $500 \mu \mathrm{L}$ (each) of Wash Buffer.

8. Peel off the assay plate bottom foil. Carefully pop all bubbles in the Separation Matrix wells using $5 \mu \mathrm{L}$ pipette tips.

9. Open the Wes's door and insert a newly-opened capillary cartridge into cartridge holder. The interior light will change from orange to blue.

10. Place the assay plate on the plate holder and make sure the plate is attached with the edge of the tray.

11. Start the Wes run and assign the file save directory. Watch for 10 minutes to make sure the sample has loaded normally (fluorescent dots travel down evenly).

12. The machine will indicate the end-time point for the run (typically takes around $3 \mathrm{~h}$ ), Figure 4, inset. After the test, take out and discard the microplate and capillary cartridge.

\subsubsection{Data analysis of Wes data}

1. Check the fluorescent standards assignment in the biotinylated ladder and each sample by clicking on Standard $\rightarrow$ Single View in the Compass Analysis Graph pane. Standard peaks for $12-230 \mathrm{kDa}$ kit are $1,29,230 \mathrm{kDa}$. $1 \mathrm{kDa}$ standard is the highest peak. The position of the $29 \mathrm{kDa}$ and $230 \mathrm{kDa}$ peaks should be similar for the ladder and the samples. If needed, correct peak position by right-clicking on peak and selecting "Not a Standard" or "Force Standard".

2. If the $1 \mathrm{kDa}$ peaks vary a lot among samples and standard, exclude that peak to increase the accuracy of the protein size assignment. To exclude the $1 \mathrm{kDa}$ standard peak for protein 
size fit, click Analysis in Edit tab. In the pop out window, under Standard tab, unclick the box for $1 \mathrm{MW}(\mathrm{kDa})$ fit. Click Apply to save the adjusted setting.

3. Confirm biotinylated ladder peaks assignment by clicking on Samples $\rightarrow$ Single View of $1^{\text {st }}$ capillary in Compass Analysis Graph pane. Peaks in $12-230 \mathrm{kDa}$ kit are $12,40,66,116$, $180,230 \mathrm{kDa}$.

4. Make sure the Sample Baseline Corrected and Fit Baseline Corrected are checked in the View Menu pull down options.

5. Name the detected peaks by going to Analysis in the Edit tab, click on the Peak Names tab in pop out window. Add names in the Analysis Groups and assign MWs (kDa), Color and Range (\%) for each peak. $10 \%$ is commonly used for Range (\%), decrease the percentage if two detected peaks have similar molecular weights. Apply setting to desired groups. Click on Apply after the peak assignment.

6. To confirm the peaks assignment, check the fitted peaks in Graph Options (right top corner of the Analysis window). Under Graph pane, assigned peaks are colored as assigned. Check the peaks recognition in each sample and adjust analysis setting if needed.

7. Sample information is listed at the bottom of the Analysis view in Peaks tab, and it includes sample name, primary antibody, capillary number, peak number, peak name, peak position, molecular weight $(\mathrm{MW}(\mathrm{kDa}))$, peak height, peak area, percentage area $(\%$ peak area/ area under the curve), peak width, signal noise ratio $(\mathrm{S} / \mathrm{N})$, averaged baseline.

8. For peaks analysis, go to the Capillaries tab at the bottom of Analysis view. The peaks areas are listed with peak names and capillary number. Choose the Area display, copy the sheet by clicking $\mathrm{Ctrl}+\mathrm{A}$ and $\mathrm{Ctrl}+\mathrm{C}$. Paste the data into an Excel file for analysis. 
9. Virtual blotting results ("lanes") available in the Compass Lane pane. Add sample, primary antibody, secondary antibody, their attributes and capillary No. information from Gels Options. Adjust display contrast with the Slider if needed. Copy or screenshot the Lane view.

10. The Compass software can be downloaded for free for further examination and plotting of the data offline.

\subsection{Primary antibody dilution optimization}

With consistent plating and culturing conditions, the hiPSC-CMs samples collected from 96-wells yield similar protein concentration, therefore the protein amount in each Wes sample loading will be similar. When using an antibody for the first time, optimal primary antibody dilution should be tested. The primary antibody needs to be at a saturating concentration to make sure the HRP signal change is proportional to protein expression difference. Over-saturation will increase the signal background and cause non-specific detection.

If a target protein has been quantified in traditional WB, a good starting point for the referencing primary antibody dilution in Wes will be to use 20 times higher antibody concentration than in traditional WB. If a target protein could be clearly identified at the expected molecular weight with referencing primary antibody dilution and system peak height/ baseline ratio $\geqslant 3$, further tests of signal linear response under this dilution could be conducted. Otherwise, increase or decrease the primary antibody dilution according to the signal.

Proper controls should be included to distinguish signal from noise and to validate detection specificity, which includes:

- Neat sample with only Antibody Diluent2 in the microwell of 'primary antibody'

- $0.1 \mathrm{x}$ sample buffer in the microwell of 'sample' with testing antibody 
- Positive and negative controls, i.e. samples confirmed to have abundant \& no target protein expression

For quantifying a protein expression level, confirmation is needed that the measurements are in the linear dynamic range. Prepare four sample attributes using one sample and varying dilutions: neat, $0.75,0.5$ and 0.25 (actual sample attributes are $0.8,0.6,0.4$ and 0.2 , because samples need to be mixed with the Fluorescent Master Mix, as described earlier).

A sample collected from a single 96-well is enough for one linearity test. Repeat the following steps with multiple samples in the same test or in multiple tests to confirm the linearity.

1. For sample preparation, label four microcentrifuge tubes as 'neat', ' 0.75 ', ' 0.5 ' and ' 0.25 '. Mix cell lysis, 0.1x sample buffer and Fluorescent Master Mix as described in Table 2.

Table 2. Sample preparation for antibody linear dynamic range test

\begin{tabular}{|c|c|c|c|}
\hline $\begin{array}{c}\text { Microcentrifuge } \\
\text { sample }\end{array}$ & Cell lysis & 0.1 xample buffer & Fluorescent \\
\hline Neat & $4 \mu \mathrm{L}$ & $0 \mu \mathrm{L}$ & $1 \mu \mathrm{L}$ \\
\hline 0.75 & $3 \mu \mathrm{L}$ & $1 \mu \mathrm{L}$ & $1 \mu \mathrm{L}$ \\
\hline 0.5 & $2 \mu \mathrm{L}$ & $2 \mu \mathrm{L}$ & $1 \mu \mathrm{L}$ \\
\hline 0.25 & $1 \mu \mathrm{L}$ & $3 \mu \mathrm{L}$ & $1 \mu \mathrm{L}$ \\
\hline
\end{tabular}

2. Other steps are the same as previously described for running an immunoassay by Wes.

3. After the immunoassay, in the Compass Analysis Graph pane, select one sample and click the View Selected on top left corner. Check the All exposures in the Graph options pull down menu. $1 \mathrm{~s}$ exposure usually has the highest peak value. If the antibody is not over-saturated, the $1 \mathrm{~s}, 2 \mathrm{~s}$, 
and $4 \mathrm{~s}$ peaks should be close to each other. Consider decreasing the antibody dilution if the peaks from different exposure times are far apart.

4. Export the peak areas as previously described (see note 6). Plot the signal over sample attributes as a dot plot.

5. Add linear regression trendline to the dot plot. Acquire R-squared value of the linear regression. R-squared value above 0.9 suggests the tested antibody dilution has linear response in the range of detection.

The optimized primary antibody dilution is acquired when the high R-squared value of linearity test is consistent, and no over-saturation is observed.

\subsection{Normalized protein expression by antibody multiplexing and total protein linear response test}

Signal normalization can be achieved by antibody multiplexing or total protein quantification. Both methods have merits. Antibody multiplexing with a loading control protein requires less material, two or more tests could be conducted from a 96-well hiPSC-CMs collection. Total protein quantification could be used when no proper loading control is available.

For antibody multiplexing, the primary antibody of a target protein and the loading control need to be mixed in a proper ratio. Tested target protein \& loading control combinations are summarized in Table 3; also see note 7. Example results are shown in Figure 5 for antibody multiplexing using Cx43 and GAPDH (loading control), including the electropherogram with peaks (with areas quantified on the bottom) and the Compass-generated lane view. 
Table 3. Wes antibody multiplexing dilution examples for use in hiPSC-CMs

\begin{tabular}{|l|l|l|l|}
\hline Target description & $\begin{array}{l}\text { Target protein } \\
\text { (antibody) }\end{array}$ & Loading control & Dilution factor \\
\hline $\begin{array}{l}\text { LDH-A: lactose dehydrogenase- } \\
\text { A linked to metabolic state }\end{array}$ & LDH (H-10) & Alpha tubulin & $1: 300 \mathrm{LDH}$ \\
(Santa Cruz sc- & (Abcam ab7291) & $1: 50$ Alpha tubulin \\
junctional protein found in & (Abcam ab11370) & (Abcam ab181602) & $1: 2000 \mathrm{GAPDH}$ \\
ventricular heart tissue & Gen43 & & \\
\hline Kir2.1 - ion channel (inward & Kir2.1 & GAPDH & $1: 10 \mathrm{Kir} 2.1$ \\
rectifier) responsible for the & (Abcam ab65796) & (Abcam ab181602) & $1: 4000 \mathrm{GAPDH}$ \\
resting membrane potential & (Alomone APC-159) & & \\
\hline
\end{tabular}

For simplicity, start making new antibody combinations by choosing two primary antibodies from the same host species. First, optimize the primary antibody dilution of each target. Make sure the multiplexed antibodies have clean baseline and are sufficiently different in molecular weight. Second, vary the antibody dilution to make the detected signals appear at a comparable level. In most cases, the expression levels of two targets are distinct and can differ by order of magnitude. Increase the antibody concentration of the less abundant target protein to balance the signal level. Or further dilute the abundantly-expressed protein antibody. Rerun the signal linear response test to make sure the diluted concentration is saturated.

If varying the antibody dilutions can't adjust the signal to a comparable level, alternative solutions are provided by Protein Simple: 
- Choose different species for the abundantly-expressed protein. Also mix secondary antibodies and ensure they reach saturation. The company provides $20 \mathrm{x}$ secondary antibody formulation to ensure saturation of the secondary antibodies.

- Apply an HRP-conjugated secondary with lower HRP load. For example, Simple Western charge secondary antibodies (Anti-Rabbit HRP PN 040-656, Anti-Mouse HRP PN 040$655)$.

- Mix unlabeled secondary with the HRP-conjugated secondary. Be aware of the stability of secondary antibody mixtures.

- Use HRP-conjugated primary antibody as direct detection. It limits the amplification effect induced by indirect detection, but it is less specific comparing with indirect detection.

Follow Protein Simple's instruction on how to apply these methods.

For signal normalization by total protein assay, total protein linear detection range needs to be identified and included in each immunoassay. Use neat, $0.75,0.5$ and 0.25 sample attributes as four detection points, conduct total protein assay as previously described. Plot the total protein signal over sample attributes and do the linear regression to determine the total protein detection range. If titrated samples show good linearity (R-squared value $>0.9$ ), the 4-times diluted sample could be used for antibody optimization and total protein assay could be used for signal normalization. If including 0.25 sample attribute influences the signal linearity, choose four attributes above 0.25 and rerun the linear detection range tests until finalizing the detection limit.

\section{7 mRNA quantification in hiPSC-CMs using Cells-to-CT ${ }^{\mathrm{TM}}$ kit and qPCR}

1. qPCR analysis is run using the Power SYBR-Green Cells-to-CT ${ }^{\mathrm{TM}}$ kit (Thermo Fisher) and following the manufacturer's instructions 
2. Prepare DNase1 and Lysis solution 1:100 and use $50 \mathrm{uL}$ of it for each well.

3. Aspirate the maintenance medium from the hiPSC-CMs. Wash cells with cold $1 \mathrm{X}$ PBS.

4. After aspirating the PBS, add $50 \mathrm{uL}$ of DNase1 and Lysis Solution to each well. Pipet up and down with the pipette set to $30 \mathrm{uL}$ (so to not introduce bubbles) 5 times.

5. Incubate plate at room temperature $\left(19-25^{\circ} \mathrm{C}\right)$ for $5 \mathrm{~min}$.

6. Add $5 \mathrm{uL}$ of stop solution to each well, mix 5 times, and incubate at room temperature for an additional 2 minutes.

7. Store samples at $-80^{\circ} \mathrm{C}$ as needed or proceed to the next step.

8. Program thermal cycler as indicated in Table 4.

Table 4. Thermal cycler settings for Reverse Transcriptase

\begin{tabular}{|c|c|c|c|c|}
\hline & Stage & Reps & Temp & Time \\
\hline Reverse & 1 & 1 & $37^{\circ} \mathrm{C}$ & 60 min \\
Transcription & & & & \\
\hline RT inactivation & 2 & 1 & $95^{\circ} \mathrm{C}$ & 5 min \\
\hline Hold & 3 & 1 & $4^{\circ} \mathrm{C}$ & indefinite \\
\hline
\end{tabular}

9. Prepare a Reverse Transcriptase Master mix of $25 \mathrm{uL}$ RT buffer, $2.5 \mathrm{uL}$ Reverse Transcriptase, and $12.5 \mathrm{uL}$ nuclease-free water per lysate.

10. Add $10 \mathrm{uL}$ of lysate per $40 \mathrm{uL}$ Reverse Transcriptase Master Mix and mix.

11. Run thermal cycler as indicated. 
12. After reverse transcriptase, store samples at $-20^{\circ} \mathrm{C}$ or proceed to the next step.

13. Program the real-time PCR instrument as indicated in Table 5. Reps (cycles) determines the level of amplification.

Table 5. Real-Time PCR Cycling Parameters

\begin{tabular}{|c|c|c|c|c|}
\hline & Stage & Reps (Cycles) & Temp & Time \\
\hline Enzyme Activation (hold) & 1 & 1 & $95^{\circ} \mathrm{C}$ & $10 \mathrm{~min}$ \\
\hline PCR (cycle) & 2 & 40 & $95^{\circ} \mathrm{C}$ & $15 \mathrm{sec}$ \\
& & & $60^{\circ} \mathrm{C}$ & $1 \mathrm{~min}$ \\
\hline Dissociation Curve & 3 & \multicolumn{3}{|c|}{ (use default settings) } \\
\hline
\end{tabular}

14. Prepare PCR cocktail as indicated in Table 6. To detect GJA1 mRNA, use Fw_GGTGGTACTCAACAGCCTTATT and Rv_ACCAACATGCACCTCTCTTATC primers and to detect GAPDH, use Fw_GGTGTGAACCATGAGAAGTATGA and Rv_GAGTCCTTCCACGATACCAAAG primers respectively.

Table 6. PCR Cocktail Conditions

\begin{tabular}{|c|c|}
\hline Component & 20uL PCRs (Each reaction) \\
\hline Power SYBR Green PCR Master Mix & $10 \mathrm{uL}$ \\
\hline Forward and Reverse PCR Primers & $250 \mathrm{nM}$ final concentration of each PCR primer \\
\hline Nuclease Free Water & variable \\
\hline cDNA & $4 \mathrm{uL}$ \\
\hline
\end{tabular}


15. Dilute forward and reverse primers in nuclease free water as needed. Add PCR cocktail and cDNA to each well of the MicroAmp ${ }^{\mathrm{TM}}$ Optical 96-well Reaction plate. Scale volumes as needed to account for 3 technical replicates and the various targets. Per one 96-well of lysate collected, about 12 different gene targets can be tested.

16. Seal MicroAmp ${ }^{\mathrm{TM}}$ Optical 96-well Reaction plate with MicroAmp ${ }^{\mathrm{TM}}$ Optical Adhesive Film and seal all edges with plastic MicroAmp ${ }^{\circledR}$ Adhesive Film Applicator to form a tight seal between the plate and adhesive film.

17. Run plate on QuantStudio ${ }^{\mathrm{TM}} 3$ Real-Time PCR instrument under the parameters listed on Table 5.

18. Use QuantStudio ${ }^{\mathrm{TM}}$ Design \& Analysis Software to extract Ct values and normalize Cx43 gene expression quantification to housekeeping gene GAPDH using standard $\Delta \Delta \mathrm{Ct}$ $\operatorname{method}(45-47)$.

\section{Example application}

We illustrate the described methods for quantification of protein and mRNA within small cell samples $(50,000$ cells) in a 96-well microplate format by examining the effects of optogenetic transduction (ChR2) on the transcript and protein levels of gap junctional protein $\mathrm{Cx} 43$.

Connexin 43 is the main gap junctional protein in ventricular cardiomyocytes with a critical role in their structural and functional maturity $(2,54)$. A previous optogenetics study, using HEK293T cells (with minimal Cx43 expression) suggested possible augmentation of $\mathrm{Cx} 43$ expression in those cells upon genetic expression of Channelrodopsin-2 (ChR2), a light-gated ion channel(55). 
Using the methods described here, we probe for effects of ChR2 on Cx43/GJA1 in human iPSCCMs from individual wells in a 96-well microplate.

With optimized Cx43 \& GAPDH multiplexing in the Wes assay, the Cx43 protein expression levels are compared in non-infected, Ad-CMV-eYFP infected and Ad-CMV-hChR2 (H134R)eYFP infected hiPSC-CMs using two different hiPSC-CM lines, iCell Cardiomyocytes ${ }^{2}$ CMC100-012-001 (female differentiated) and MyCell hiPSC-CM-1X 01395 (male differentiated). In addition, GJA1 normalized to GAPDH mRNA levels were quantified in the respective conditions using the Cells-to-Ct kit and qPCR.

The results suggest highest Cx43 protein expression levels (after normalization by GAPDH) in ChR2 transduced hiPSC-CMs when compared to Ad-CMV-eYFP infected and non-infected hiPSC-CM cell lines (Figure 6a-b). At the transcriptional level, elevated GJA1 is also seen in ChR2-treated hiPSC-CMs compared to the eYFP-expressing cells but not compared to the untreated (Figure 6c-d). The results indicate that the presence of ChR2 may enhance Cx43 expression in hiPSC-CMs, though no statistical significance was reached at the transcription level. Although the mechanism is not clear and warrants further investigation, the findings suggest that an optogenetic perturbation may have an overall positive effect on hiPSC-CMs coupling.

\section{Notes}

1. Timing the water bath time is critical for cell viability when handling the iPSC-CMs.

2. Keeping the integrity of the cell monolayer is important for a successful protein collection. Proper dilution of fibronectin, sufficient fibronectin coating time, gentle operation during hiPSCMs thaw and culture could help improve cell attachment and viability. 
3. In the cell lysing process, timing is important - try to operate as quickly as possible to avoid sample degradation. In, addition, all operations should be conducted on ice.

4. To minimize the difference in migration speed due to protein concentration, it is preferable to use samples with the same dilution factor in a particular run.

5. Minimize bubble formation by pointing pipette tip to the bottom of each well while pipetting and do it gently.

6. Default exposure is "High Dynamic Range 4.0"; different exposure times yield similar results.

7. Testing is required for each new antibody being considered. Antibodies working in standard WB may not work with Wes, even for the same samples. Different lot numbers of the same product number antibody also can produce variable results and need to be re-tested.

ProteinSimple maintains a database of Wes-tested antibodies and target proteins in different cell types that can be useful.

\section{Author contributions}

WZL, JLH and EE conceived the project. WZL designed and performed the Wes system validation and optimization, antibody multiplexing optimization, total protein linear response test and wrote the first draft. JLH and WZL designed and conducted proof of concept experiments, including qPCR and Wes quantification of Cx43 in non-infected, Ad-eYFP infected and Ad-CMV-hChR2 (H134R)-EYFP infected hiPSC-CMs. WZL, JLH and EE edited the draft. 


\section{Acknowledgements}

This work was supported in part by grants from the National Institutes of Health (R01-HL144157, R21-EB026152) and the National Science Foundation (EFMA 1830941, CBET1705645, and PFI 1827535). 


\section{References}

1. Magdy T, Schuldt AJT, Wu JC, Bernstein D, Burridge PW (2018) Human induced pluripotent stem cell (hipsc)-derived cells to assess drug cardiotoxicity: Opportunities and problems. Annual review of pharmacology and toxicology 58:83-103.

doi:10.1146/annurev-pharmtox-010617-053110

2. Gintant G, Burridge P, Gepstein L, Harding S, Herron T, Hong C, Jalife J, Wu JC (2019) Use of human induced pluripotent stem cell-derived cardiomyocytes in preclinical cancer drug cardiotoxicity testing: A scientific statement from the american heart association. Circ Res 125 (10):e75-e92. doi:10.1161/res.0000000000000291

3. Entcheva E, Kay MW (2020) Cardiac optogenetics: A decade of enlightenment. Nature reviews Cardiology. doi:10.1038/s41569-020-00478-0

4. Zhang H, Cohen AE (2017) Optogenetic approaches to drug discovery in neuroscience and beyond. Trends Biotechnol 35 (7):625-639. doi:10.1016/j.tibtech.2017.04.002

5. Klimas A, Ortiz G, Boggess SC, Miller EW, Entcheva E (2020) Multimodal on-axis platform for all-optical electrophysiology with near-infrared probes in human stem-cellderived cardiomyocytes. Prog Biophys Mol Biol 154:62-70.

doi:10.1016/j.pbiomolbio.2019.02.004

6. Klimas A, Ambrosi CM, Yu J, Williams JC, Bien H, Entcheva E (2016) Optodyce as an automated system for high-throughput all-optical dynamic cardiac electrophysiology. Nature communications 7:11542. doi:10.1038/ncomms 11542

7. Sharma A, Burridge PW, McKeithan WL, Serrano R, Shukla P, Sayed N, Churko JM, Kitani T, Wu H, Holmstrom A, Matsa E, Zhang Y, Kumar A, Fan AC, Del Alamo JC, 
Wu SM, Moslehi JJ, Mercola M, Wu JC (2017) High-throughput screening of tyrosine kinase inhibitor cardiotoxicity with human induced pluripotent stem cells. Sci Transl Med 9 (377). doi:10.1126/scitranslmed.aaf2584

8. McKeithan WL, Savchenko A, Yu MS, Cerignoli F, Bruyneel AAN, Price JH, Colas AR, Miller EW, Cashman JR, Mercola M (2017) An automated platform for assessment of congenital and drug-induced arrhythmia with hipsc-derived cardiomyocytes. Frontiers in physiology 8 (OCT):1-12. doi:10.3389/fphys.2017.00766

9. Cerignoli F, Charlot D, Whittaker R, Ingermanson R, Gehalot P, Savchenko A, Gallacher DJ, Towart R, Price JH, McDonough PM, Mercola M (2012) High throughput measurement of ca2+ dynamics for drug risk assessment in human stem cell-derived cardiomyocytes by kinetic image cytometry. Journal of Pharmacological and Toxicological Methods 66 (3):246-256. doi:10.1016/j.vascn.2012.08.167

10. Dempsey GT, Chaudhary KW, Atwater N, Nguyen C, Brown BS, McNeish JD, Cohen AE, Kralj JM (2016) Cardiotoxicity screening with simultaneous optogenetic pacing, voltage imaging and calcium imaging. J Pharmacol Toxicol Methods 81:240-250. doi:10.1016/j.vascn.2016.05.003

11. Laemmli UK (1970) Cleavage of structural proteins during the assembly of the head of bacteriophage t4. Nature 227 (5259):680-685. doi:10.1038/227680a0

12. Towbin H, Staehelin T, Gordon J (1979) Electrophoretic transfer of proteins from polyacrylamide gels to nitrocellulose sheets: Procedure and some applications. Proc Natl Acad Sci U S A 76 (9):4350-4354. doi:10.1073/pnas.76.9.4350

13. Burnette WN (1981) "Western blotting": Electrophoretic transfer of proteins from sodium dodecyl sulfate--polyacrylamide gels to unmodified nitrocellulose and radiographic 
detection with antibody and radioiodinated protein a. Anal Biochem 112 (2):195-203. doi:10.1016/0003-2697(81)90281-5

14. Treindl F, Ruprecht B, Beiter Y, Schultz S, Döttinger A, Staebler A, Joos TO, Kling S, Poetz O, Fehm T, Neubauer H, Kuster B, Templin MF (2016) A bead-based western for high-throughput cellular signal transduction analyses. Nature communications 7:12852. doi:10.1038/ncomms 12852

15. Hughes AJ, Herr AE (2012) Microfluidic western blotting. Proc Natl Acad Sci U S A 109 (52):21450-21455. doi:10.1073/pnas.1207754110

16. Hu B, Li J, Mou L, Liu Y, Deng J, Qian W, Sun J, Cha R, Jiang X (2017) An automated and portable microfluidic chemiluminescence immunoassay for quantitative detection of biomarkers. Lab Chip 17 (13):2225-2234. doi:10.1039/c71c00249a

17. Lin Q, Wu J, Fang X, Kong J (2020) Washing-free centrifugal microchip fluorescence immunoassay for rapid and point-of-care detection of protein. Anal Chim Acta 1118:1825. doi:10.1016/j.aca.2020.04.031

18. Hughes AJ, Spelke DP, Xu Z, Kang CC, Schaffer DV, Herr AE (2014) Single-cell western blotting. Nat Methods 11 (7):749-755. doi:10.1038/nmeth.2992

19. Bietlot HP, Girard M (1997) Analysis of recombinant human erythropoietin in drug formulations by high-performance capillary electrophoresis. Journal of Chromatography A 759 (1):177-184. doi:https://doi.org/10.1016/S0021-9673(96)00767-4

20. O'Neill RA, Bhamidipati A, Bi X, Deb-Basu D, Cahill L, Ferrante J, Gentalen E, Glazer M, Gossett J, Hacker K, Kirby C, Knittle J, Loder R, Mastroieni C, MacLaren M, Mills T, Nguyen U, Parker N, Rice A, Roach D, Suich D, Voehringer D, Voss K, Yang J, Yang T, Vander Horn PB (2006) Isoelectric focusing technology quantifies protein signaling in 
25 cells. Proceedings of the National Academy of Sciences 103 (44):16153-16158. doi:10.1073/pnas.0607973103

21. Anderson GJ, M. Cipolla C, Kennedy RT (2011) Western blotting using capillary electrophoresis. Analytical Chemistry 83 (4):1350-1355. doi:10.1021/ac102671n

22. Harris VM (2015) Protein detection by simple western ${ }^{\mathrm{TM}}$ analysis. Methods Mol Biol 1312:465-468. doi:10.1007/978-1-4939-2694-7_47

23. Beekman C, Janson AA, Baghat A, van Deutekom JC, Datson NA (2018) Use of capillary western immunoassay (wes) for quantification of dystrophin levels in skeletal muscle of healthy controls and individuals with becker and duchenne muscular dystrophy. PLoS One 13 (4):e0195850. doi:10.1371/journal.pone.0195850

24. Farnaby W, Koegl M, Roy MJ, Whitworth C, Diers E, Trainor N, Zollman D, Steurer S, Karolyi-Oezguer J, Riedmueller C, Gmaschitz T, Wachter J, Dank C, Galant M, Sharps B, Rumpel K, Traxler E, Gerstberger T, Schnitzer R, Petermann O, Greb P, Weinstabl H, Bader G, Zoephel A, Weiss-Puxbaum A, Ehrenhöfer-Wölfer K, Wöhrle S, Boehmelt G, Rinnenthal J, Arnhof H, Wiechens N, Wu MY, Owen-Hughes T, Ettmayer P, Pearson M, McConnell DB, Ciulli A (2019) Baf complex vulnerabilities in cancer demonstrated via structure-based protac design. Nat Chem Biol 15 (7):672-680. doi:10.1038/s41589-0190294-6

25. Park HJ, Kim MJ, Rothenberger C, Kumar A, Sampson EM, Ding D, Han C, White K, Boyd K, Manohar S, Kim YH, Ticsa MS, Gomez AS, Caicedo I, Bose U, Linser PJ, Miyakawa T, Tanokura M, Foster TC, Salvi R, Someya S (2019) Gsta4 mediates reduction of cisplatin ototoxicity in female mice. Nature communications 10 (1):4150. doi:10.1038/s41467-019-12073-0 
26. Schneider JS, Aras R, Williams CK, Koprich JB, Brotchie JM, Singh V (2019) Gm1 ganglioside modifies $\alpha$-synuclein toxicity and is neuroprotective in a rat $\alpha$-synuclein model of parkinson's disease. Scientific reports 9 (1):8362. doi:10.1038/s41598-019$42847-\mathrm{x}$

27. Alterman JF, Godinho B, Hassler MR, Ferguson CM, Echeverria D, Sapp E, Haraszti RA, Coles AH, Conroy F, Miller R, Roux L, Yan P, Knox EG, Turanov AA, King RM, Gernoux G, Mueller C, Gray-Edwards HL, Moser RP, Bishop NC, Jaber SM, Gounis MJ, Sena-Esteves M, Pai AA, DiFiglia M, Aronin N, Khvorova A (2019) A divalent sirna chemical scaffold for potent and sustained modulation of gene expression throughout the central nervous system. Nat Biotechnol 37 (8):884-894. doi:10.1038/s41587-019-0205-0

28. Pandey R, Yang Y, Jackson L, Ahmed RP (2016) Micrornas regulating meis1 expression and inducing cardiomyocyte proliferation. Cardiovasc Regen Med 3

29. Lu G, Li J, Zhai Y, Li Q, Xie D, Zhang J, Xiao Y, Gao X (2019) Spironolactone suppresses aldosterone-induced kv1.5 expression by attenuating mineralocorticoid receptor-nox1/2/4-mediated ros generation in neonatal rat atrial myocytes. Biochem Biophys Res Commun 520 (2):379-384. doi:10.1016/j.bbrc.2019.10.039

30. Tabebordbar M, Zhu K, Cheng JKW, Chew WL, Widrick JJ, Yan WX, Maesner C, Wu EY, Xiao R, Ran FA, Cong L, Zhang F, Vandenberghe LH, Church GM, Wagers AJ (2016) In vivo gene editing in dystrophic mouse muscle and muscle stem cells. Science 351 (6271):407-411. doi:10.1126/science.aad5177

31. Lue Y, Gao C, Swerdloff R, Hoang J, Avetisyan R, Jia Y, Rao M, Ren S, Atienza V, Yu J, Zhang Y, Chen M, Song Y, Wang Y, Wang C (2018) Humanin analog enhances the 
protective effect of dexrazoxane against doxorubicin-induced cardiotoxicity. Am J Physiol Heart Circ Physiol 315 (3):H634-h643. doi:10.1152/ajpheart.00155.2018

32. Schiattarella GG, Altamirano F, Tong D, French KM, Villalobos E, Kim SY, Luo X, Jiang N, May HI, Wang ZV, Hill TM, Mammen PPA, Huang J, Lee DI, Hahn VS, Sharma K, Kass DA, Lavandero S, Gillette TG, Hill JA (2019) Nitrosative stress drives heart failure with preserved ejection fraction. Nature 568 (7752):351-356. doi:10.1038/s41586-019-1100-z

33. Beauverger P, Ozoux ML, Bégis G, Glénat V, Briand V, Philippo MC, Daveu C, Tavares G, Roy S, Corbier A, Briand P, Dorchies O, Bauchet AL, Nicolai E, Duclos O, Tamarelle D, Pruniaux MP, Muslin AJ, Janiak P (2020) Reversion of cardiac dysfunction by a novel orally available calcium/calmodulin-dependent protein kinase ii inhibitor, ra306, in a genetic model of dilated cardiomyopathy. Cardiovasc Res 116 (2):329-338. doi:10.1093/cvr/cvZ097

34. Li W, Han JL, Entcheva E (2020) Syncytium cell growth increases kir2.1 contribution in human ipsc-cardiomyocytes. American Journal of Physiology-Heart and Circulatory Physiology 319 (5):H1112-H1122. doi:10.1152/ajpheart.00148.2020

35. Guo L, Eldridge S, Furniss M, Mussio J, Davis M (2015) Use of human induced pluripotent stem cell-derived cardiomyocytes (hipsc-cms) to monitor compound effects on cardiac myocyte signaling pathways. Current protocols in chemical biology 7 (3):141185. doi:10.1002/9780470559277.ch150035

36. Guo L, Eldridge S, Furniss M, Mussio J, Davis M (2018) Role of mcl-1 in regulation of cell death in human induced pluripotent stem cell-derived cardiomyocytes in vitro. Toxicol Appl Pharmacol 360:88-98. doi:10.1016/j.taap.2018.09.041 
37. Hernandez I, Baio JM, Tsay E, Martinez AF, Fuentes TI, Bailey LL, Hasaniya NW, Kearns-Jonker M (2018) Short-term hypoxia improves early cardiac progenitor cell function in vitro. Am J Stem Cells 7 (1):1-17

38. Zhong Q, Laco F, Liao MC, Woo TL, Oh SKW, Chai CLL (2018) Influencing the fate of cardiac and neural stem cell differentiation using small molecule inhibitors of alk5. Stem cells translational medicine 7 (10):709-720. doi:10.1002/sctm.17-0246

39. Bezzerides VJ, Caballero A, Wang S, Ai Y, Hylind RJ, Lu F, Heims-Waldron DA, Chambers KD, Zhang D, Abrams DJ, Pu WT (2019) Gene therapy for catecholaminergic polymorphic ventricular tachycardia by inhibition of $\mathrm{ca}(2+) /$ calmodulin-dependent kinase ii. Circulation 140 (5):405-419. doi:10.1161/circulationaha.118.038514

40. Saiki RK, Scharf S, Faloona F, Mullis KB, Horn GT, Erlich HA, Arnheim N (1985) Enzymatic amplification of beta-globin genomic sequences and restriction site analysis for diagnosis of sickle cell anemia. Science 230 (4732):1350-1354. doi:10.1126/science. 2999980

41. Mullis KB (1990) The unusual origin of the polymerase chain reaction. Sci Am 262 (4):56-61, 64-55. doi:10.1038/scientificamerican0490-56

42. Xia C, Fan J, Emanuel G, Hao J, Zhuang X (2019) Spatial transcriptome profiling by merfish reveals subcellular rna compartmentalization and cell cycle-dependent gene expression. Proc Natl Acad Sci U S A 116 (39):19490-19499.

doi:10.1073/pnas.1912459116

43. Higuchi R, Fockler C, Dollinger G, Watson R (1993) Kinetic pcr analysis: Real-time monitoring of DNA amplification reactions. Bio/Technology 11 (9):1026-1030. doi:10.1038/nbt0993-1026 
44. Heid CA, Stevens J, Livak KJ, Williams PM (1996) Real time quantitative pcr. Genome research 6 (10):986-994. doi:10.1101/gr.6.10.986

45. Schmittgen TD, Livak KJ (2008) Analyzing real-time pcr data by the comparative c(t) method. Nat Protoc 3 (6):1101-1108. doi:10.1038/nprot.2008.73

46. Livak KJ, Schmittgen TD (2001) Analysis of relative gene expression data using realtime quantitative pcr and the 2(-delta delta $\mathrm{c}(\mathrm{t}))$ method. Methods 25 (4):402-408. doi:10.1006/meth.2001.1262

47. Nolan T, Hands RE, Bustin SA (2006) Quantification of mrna using real-time rt-pcr. Nature Protocols 1 (3):1559-1582. doi:10.1038/nprot.2006.236

48. Van Peer G, Mestdagh P, Vandesompele J (2012) Accurate rt-qpcr gene expression analysis on cell culture lysates. Scientific reports 2:222. doi:10.1038/srep00222

49. Babiarz JE, Ravon M, Sridhar S, Ravindran P, Swanson B, Bitter H, Weiser T, Chiao E, Certa U, Kolaja KL (2012) Determination of the human cardiomyocyte mrna and mirna differentiation network by fine-scale profiling. Stem cells and development 21 (11):19561965. doi:10.1089/scd.2011.0357

50. Zhang Y, Cao N, Huang Y, Spencer CI, Fu JD, Yu C, Liu K, Nie B, Xu T, Li K, Xu S, Bruneau BG, Srivastava D, Ding S (2016) Expandable cardiovascular progenitor cells reprogrammed from fibroblasts. Cell Stem Cell 18 (3):368-381.

doi:10.1016/j.stem.2016.02.001

51. Conway M, Xu T, Kirkpatrick A, Ripp S, Sayler G, Close D (2020) Real-time tracking of stem cell viability, proliferation, and differentiation with autonomous bioluminescence imaging. BMC Biol 18 (1):79. doi:10.1186/s12915-020-00815-2 
52. Ambrosi CM, Entcheva E (2014) Optogenetic control of cardiomyocytes via viral delivery. Methods Mol Biol 1181:215-228. doi:10.1007/978-1-4939-1047-2_19

53. Yu J, Entcheva E (2016) Inscribing optical excitability to non-excitable cardiac cells: Viral delivery of optogenetic tools in primary cardiac fibroblasts. Methods Mol Biol 1408:303-317. doi:10.1007/978-1-4939-3512-3_21

54. Kucera JP, Rohr S, Rudy Y (2002) Localization of sodium channels in intercalated disks modulates cardiac conduction. CircRes 91 (12):1176-1182

55. Jia Z, Valiunas V, Lu Z, Bien H, Liu H, Wang HZ, Rosati B, Brink PR, Cohen IS, Entcheva E (2011) Stimulating cardiac muscle by light: Cardiac optogenetics by cell delivery. Circ Arrhythm Electrophysiol 4 (5):753-760. doi:10.1161/CIRCEP.111.964247 


\section{Figures}



Figure 1. Small hiPSC-CM sample protein and mRNA quantification overview

(a) hiPSC-CMs lysates collected from each of the 96-wells are used directly for protein or mRNA quantification. For Wes quantification, the cell lysate is mixed with reaction reagent and denatured at $75^{\circ} \mathrm{C}$ for $10 \mathrm{~min}$. (b) Twenty-four samples can be loaded in each Wes microplate and quantified concurrently. After 3-5 hours of Wes run, quantification results including target protein linear response, antibody multiplexing or total protein assays can be analyzed in the Compass software, and sample comparison can be displayed using pseudo-gel-bands. (c) For qPCR quantification, 
mRNA in the whole cell lysates from individual wells can be quantified with the Cells-to-CT qPCR approach, involving the steps shown; quantification is by the $\Delta \Delta \mathrm{Ct}$ method. Figure created with Biorender. 


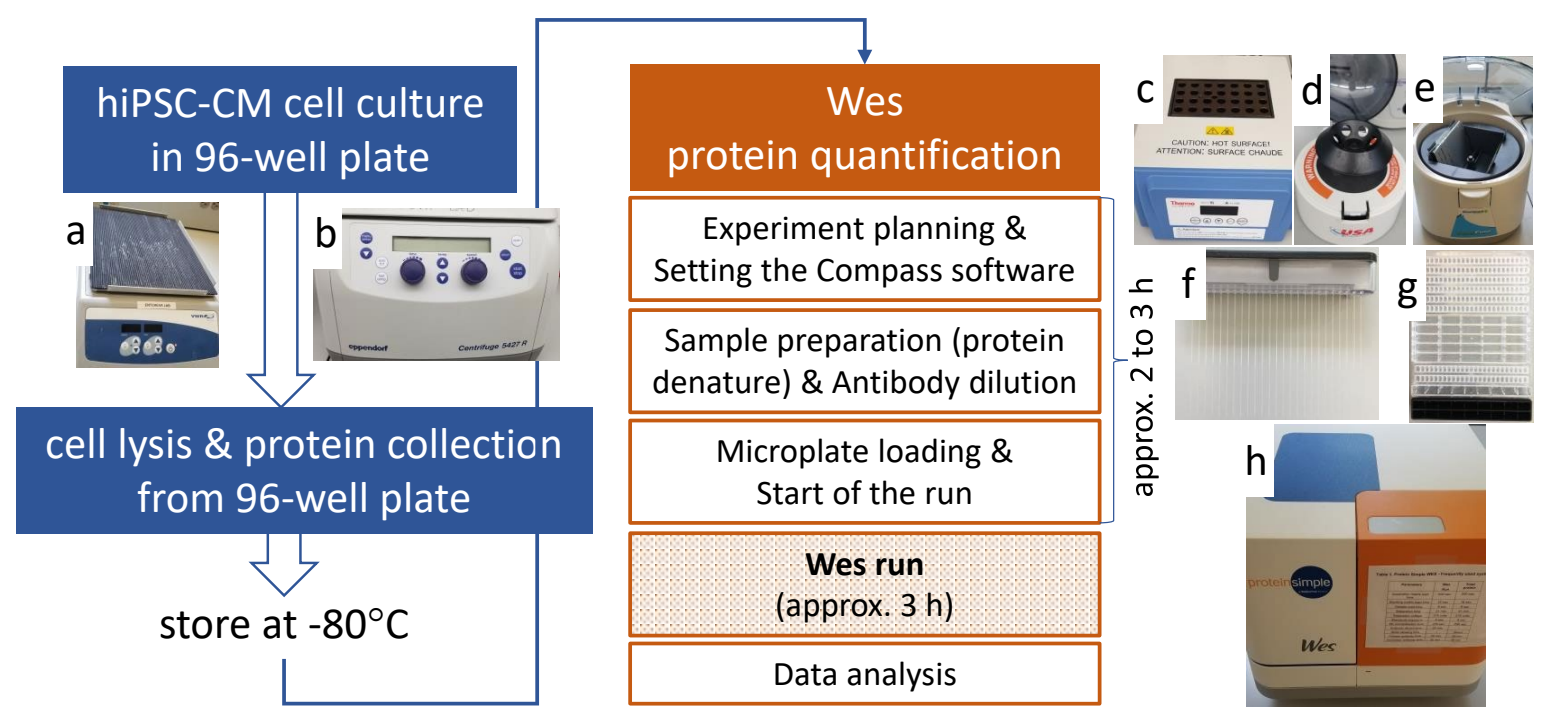

Figure 2. Detailed workflow and equipment needed for Wes protein quantification

Wes protein analysis workflow can be separated to three main parts: protein collection, experiment preparation and data analysis. Plate shaker (a), a box of ice and refrigerated high-speed centrifuge (b) are needed in protein collection. In experiment preparation, the heating block (c), microtube centrifuge (d) and microplate centrifuge (e) are needed. Wes capillary set (f) and the prepared microplate $(\mathrm{g})$ are inserted in the Wes machine $(\mathrm{h})$ for the run. 


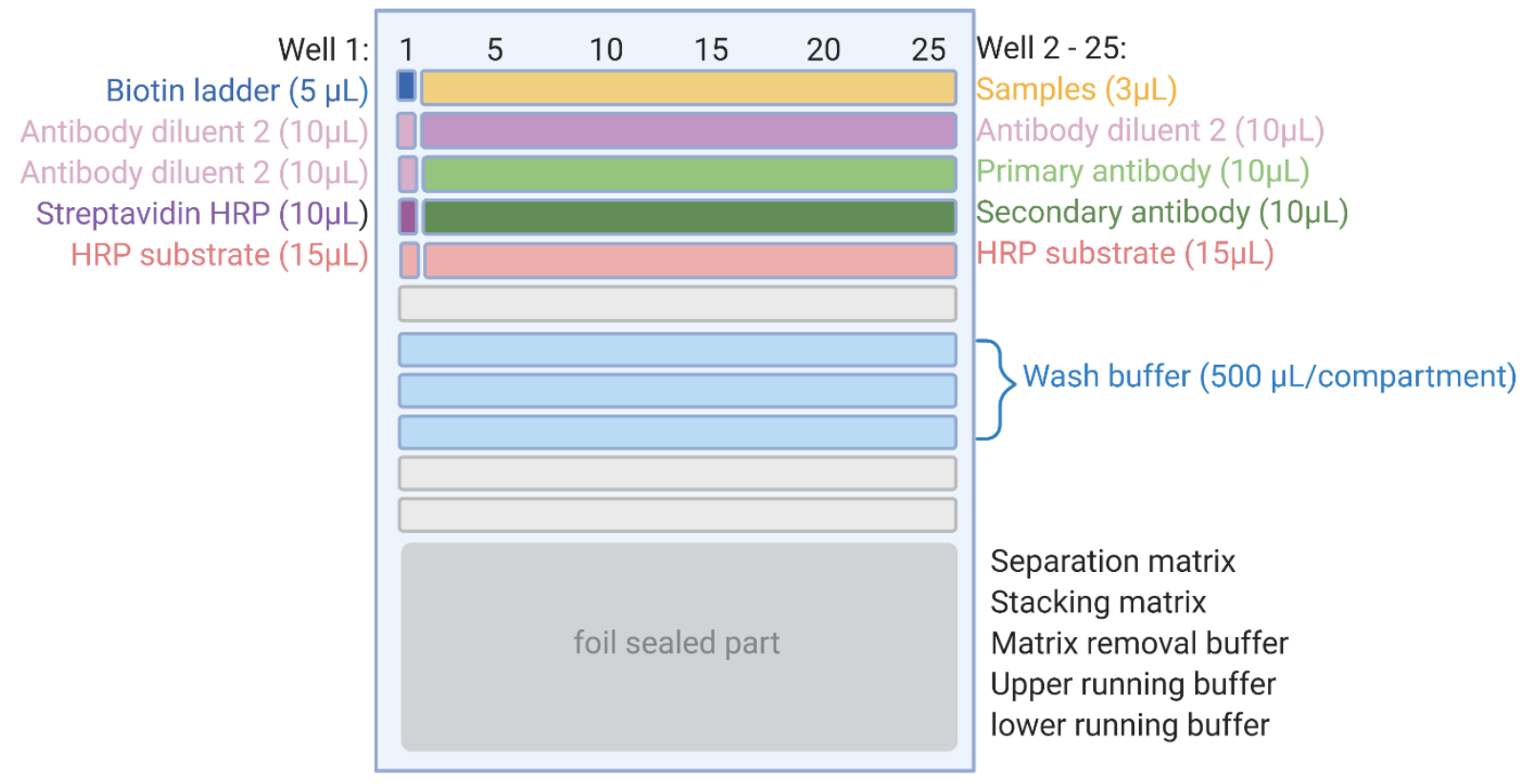

Figure 3. Microplate loading with reagents

The layout of a Wes microplate includes 6 rows of wells ( 25 wells per row), 5 rows of wash buffer troughs and bottom manufactured part. The first 5 rows of oval wells and the first 3 rows of wash buffer troughs are usually loaded as indicated in the figure. Figure created with Biorender. 

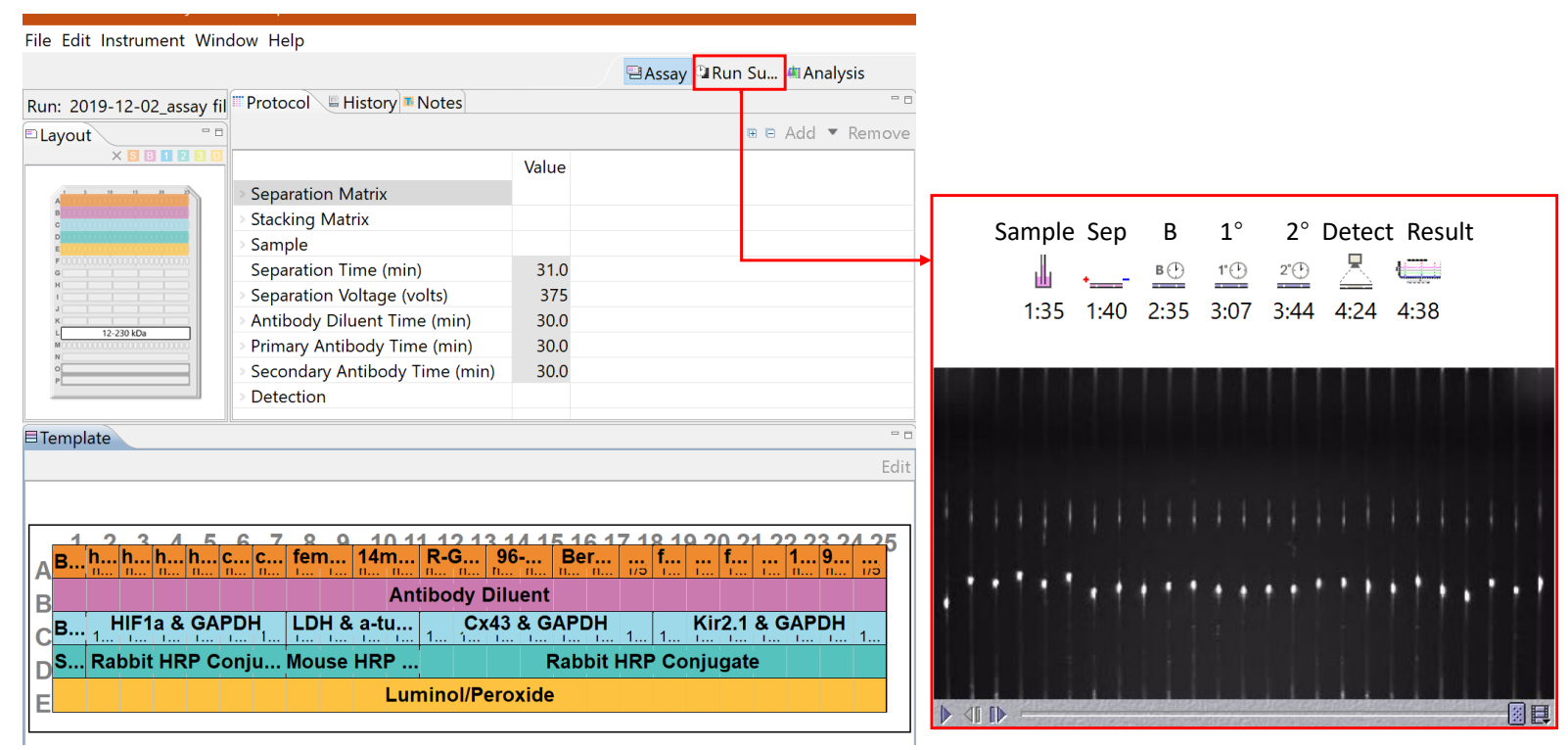

\section{Figure 4. Compass - data acquisition and analysis software}

After creating a new run, the experimental settings, including testing protocol, sample layout and antibody dilutions are saved as Assay in Compass Data File (.cbz). Once a new run is started, the experimental timeline can be seen in the Run summary. The progression of the sample loading can be monitored in real-time in the Run summary, which is stored as a video after the experiment. Quantification result and signal analysis are available in Analysis. 


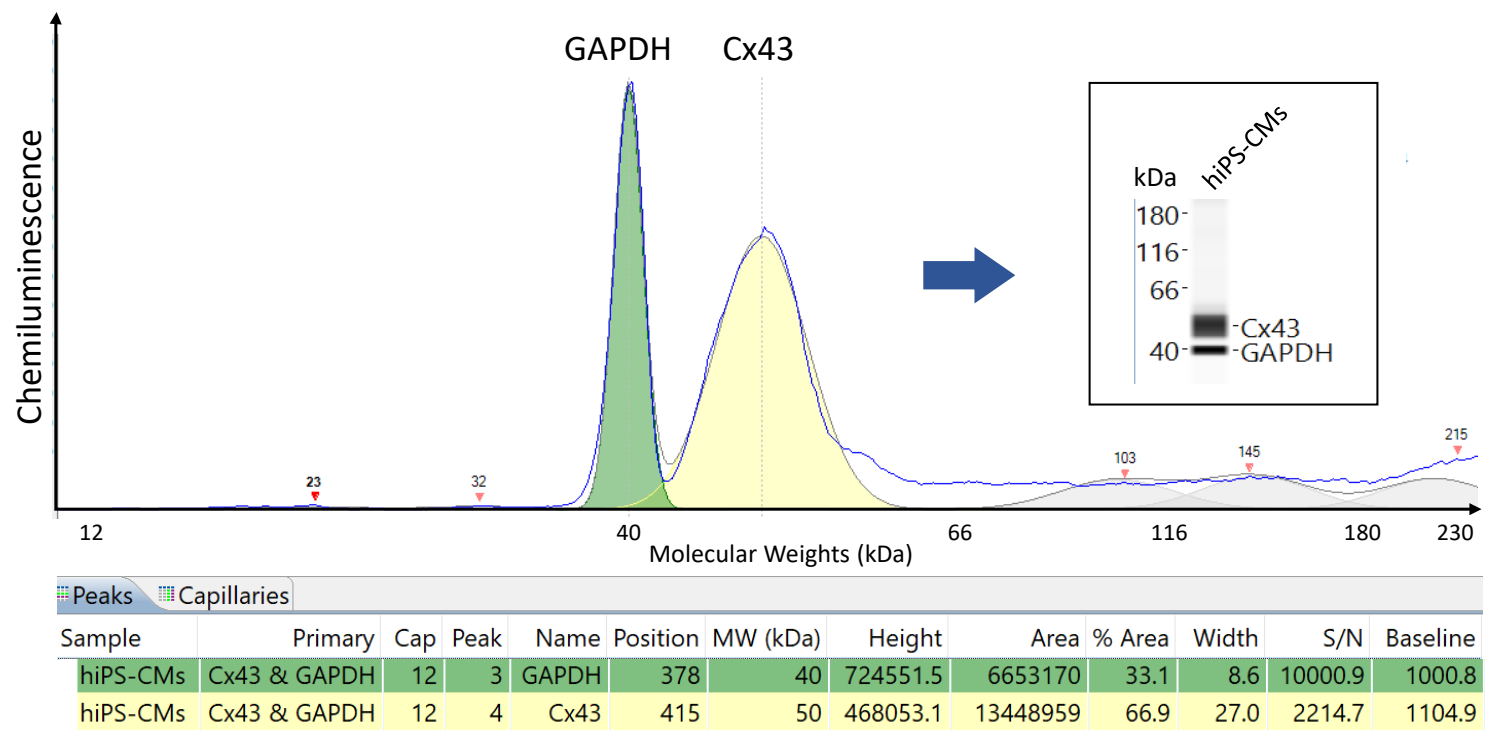

Figure 5. Example result of Cx43 \& GAPDH multiplexing in human iPSC-CMs

Electropherogram and its conversion to a virtual lane view result of Cx43 \& GAPDH multiplexing, using a 96-well collected human iPSC-CMs sample. Information including peak position, molecular weights, height, area, percentage area, width, signal noise ratio and baseline are quantified in the Compass software. 


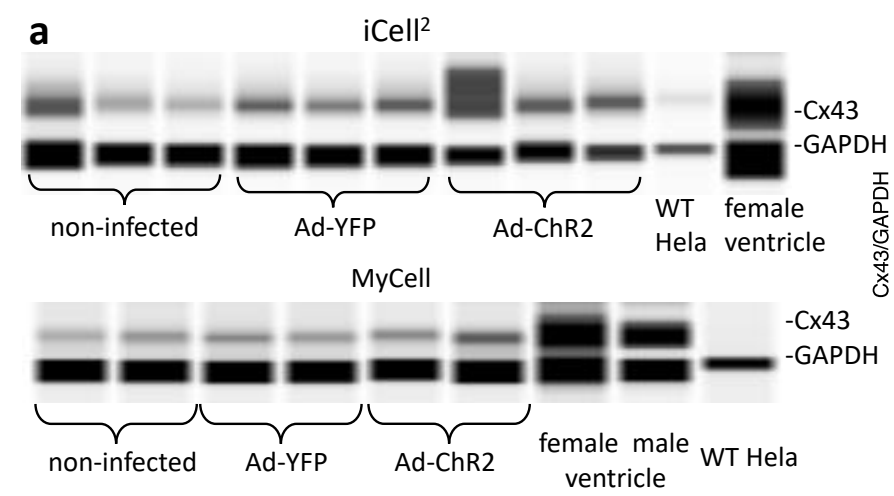

b
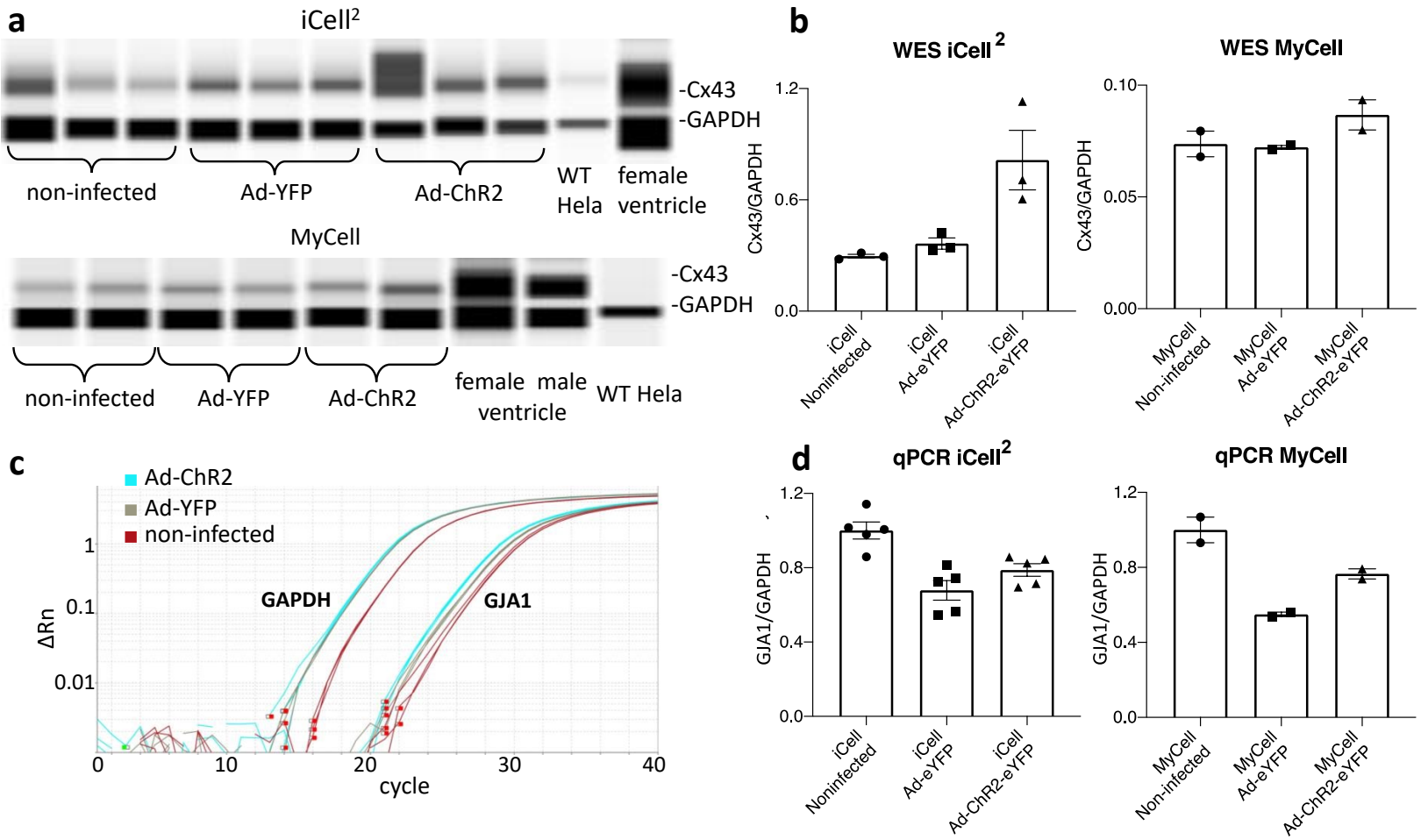

Figure 6. Quantification of protein (Cx43) and mRNA (GJA1) after ChR2 expression in female iCell ${ }^{2}$ and male MyCell hiPSC-CMs

(a-b) Protein quantification $\left(\mathrm{Cx} 43\right.$ \& GAPDH) in $\mathrm{iCell}^{2}(\mathrm{a})$ and MyCell iPSC-CMs from individual 96-wells (control non-infected samples, Ad-eYFP expressing cardiomyocytes and Ad-ChR2eYFP-expressing cardiomyocytes); human ventricular tissues as positive control and wild type HeLa as negative control. Panel (a) shows the pseudo-bands automatically generated in the Compass software. Panel (b) displays the normalized Cx43/GAPDH values automatically calculated from areas under the curve in the electropherograms. Data are presented as $n=3$ technical replicates in $\mathrm{iCell}^{2}$ and $\mathrm{n}=2$ biological replicates in MyCell. (c-d) mRNA quantification (GJA1 \& GAPDH) in iCell² (a) and MyCell iPSC-CMs from individual 96-wells. Panel (c) shows example PCR amplification curves from one run with iCell ${ }^{2}$ samples. Panel (d) shows the 
normalized values GJA1/GAPDH calculated using the $\Delta \Delta \mathrm{Ct}$ method. Data are presented as $\mathrm{n}=5$ biological replicates with $\mathrm{n}=3$ technical replicates for iCell ${ }^{2}$ and $\mathrm{n}=2$ biological replicates with $\mathrm{n}=3$ technical replicates for MyCell. All biological replicates displayed along with the mean. 